\title{
The Conundrum of Queen Min's Portrait: A Denied or Partial Identity?
}

Antonetta L. Bruno*, Kukjin Kim**

\section{Introduction: Changing Identities ${ }^{1}$}

Thousands of words have been written on Queen Min, on her personality and her political role. Indeed, there is an abundance of historical accounts, travel diaries, newspaper articles, official documents, academic papers, musicals, TV dramas, movies, clips on YouTube and so on. Criticized, admired or both, Queen Min undoubtedly played an important role in the destiny of Korea, and historians agree that she was one of the most powerful figures in the country in the twenty years between 1874 and $1895 .^{2}$ In foreign policy she engaged in making strategic alliances with

* Lead author. Full professor at the Department "Italian Institute of Oriental Studies," Sapienza University of Rome. E-mail: antonetta.bruno@uniroma1.it.

** Corresponding author. Author of the chapter "Women's portraits in the Chosŏn dynasty". Lecturer at the Department "Italian Institute of Oriental Studies," Sapienza University of Rome. E-mail: kukjin.kim@uniroma1.it.

1 It is not the intention of this paper to review theories on identity. Here, "identity" refers to how others perceive Queen Min rather than how she perceived herself. For a general definition of identity, see Jan E. Stets and Richard T. Serpe, "Identity Theory," in Handbook of Social Psychology, eds. John DeLamater and Amanda Ward (Dordrecht: Springer, 2013): 31-60.

2 For previous studies on Queen Min, see Yi Paeyong, "Kaehwagi Myŏngsŏng Hwanghu Minbi ŭi Chŏngch'ijŏk Yŏk'al [Political Role of Queen Min in the Enli 
other countries to counterbalance Japanese hegemony. In domestic policy she was ensnared in internal struggles between conservative and reformist parties and, in the parallel struggle between her father-in-law, the regent Yi Haŭng known as Taewŏngun (1821-1898), and his son King Kojong (1852-1919). From the perspective of strategic media treatment of royal families (the clearest example being the modern British royal family), Queen Min's image has been transformed more than once to capture people's imaginations accompanied by an attempt to give her a face, a visual identity. In line with how images change according to mainstream models, her gender has been seen as a salient aspect of her identity, i.e., as a means to minimize her active role in the political arena of the past, or to magnify it as regards globalization and the subsequent warming of relations with Russia. Within the discourse of Korean nationalism, she has passed from anti-Confucian consort to exemplary Mother of the Nation. ${ }^{3}$

Queen Min was the wife of the 26th king of the Yi Dynasty, Kojong (高宗, r. 1863-1907). ${ }^{4}$ She was called 'daughter of Min Chirok (閔致祿)'

ghtenment Period]," Kuksagwan Nonch'ong [Bulletin of National Institute of Korean History] 66 (1995): 61-111; Sŏ Yŏnghŭi, "Myŏngsŏng Hwanghu Yŏn'gu [Myoungsung the Empress]," Yǒksa Bip'yŏng [Critical Review of History] Nov. (2001): 101-119; Sŏ Yŏnghŭi, "Myŏngsŏng Hwanghu Chaep'yŏngga [Revaluation on Myoungsung the Empress]," Yǒksa Bip'yŏng [Critical Review of History] Sep. (2002): 328-349; Yi Minwŏn, "Kŭndae ŭi Kungjung Yŏsŏng - Myŏngsŏng Hwanghu ŭi Kwŏllyŏk kwa Hisaeng [The Last Queen of Chosun Dynasty - Her Political Power and Sacrifice -]," Sahak Yǒn'gu [The Review of Korean History] 77 (2005): 65-99; Chang Yŏngsuk, "Sŏyangin ŭi Kyŏnmun'gi rŭl t'onghae pon Myŏngsŏng Hwanghu ŭi chŏngch'ijŏk wisang gwa Yŏk'al [The Political Status and the role of Empress Myeongseong Hwanghu - As Examined from the Travel Records of the Westerners -]," Han'guk Kŭnhyŏndaesa Yŏn'gu [Journal of Korean Modern and Contemporary History] 35 (2005): 7-31.

3 On varying images of Queen Min, see Kwon Haengka, "Myŏngsŏng Hwanghu wa Kungmo ŭi P'yosang [Representation of Empress Myeongseong as the Mother of the Nation]," Misulsa Yŏn'gu [Journal of Art History] 21 (2007): 203-230.

4 The article does not intend to go into detail about Min's life; this will be mentioned only briefly here. 
before marriage, 'Her Palace Majesty (中殿媽媽)' after marriage, and 'Myŏngsŏng hwanghu (明成皇后)' after her death. Born on the 25th of September 1851, she was orphaned by the age of eight. Among her ancestors were two queens; ${ }^{5}$ others had been well-placed bureaucrats, although by the time she was born the clan has lost its wealth and power. She was married to King Kojong in 1866 and was subsequently described as a quiet obedient young lady, devoted to reading books, including history books, and intent on learning court etiquette. ${ }^{6}$ She was ignored by her husband for many years, and the king's first son was born to a palace woman of common birth (the child suddenly died in unknown circumstances ten years later). ${ }^{7}$ Min finally became pregnant in 1871 when she was 20. Her close relationship with shamans is mentioned several times during her life: while expecting her child she invited many shamans to perform rituals to assure a smooth pregnancy and ordered them to perform many others when the child died three days after his birth. ${ }^{8}$

Queen Min's various identities encompass her personal role as wife of the king and her political role as queen. Although her historical role is essential to the understanding of her character, this itself is one of the reasons for the blurring of her identity. Indeed, it is her active participation in areas that were deemed the domain of men that makes it difficult to conceive her as an individual and as a historical figure. Her interference in political affairs did not fit in with Confucian ideology, which encouraged repression in women so they conformed to the ideals of traditional virtuous womanhood. On the one hand, Min as a historical figure -

5 The wives of the third king of the Yi Dynasty, Taejong (太宗, r. 1401-1418), and of the 19th king, Sukjong (肅宗, r. 1675-1720).

6 Kojongshillok. 36 kwŏn, Kojong 34 nyŏn 11 wŏl 22 il [Veritable Records of King Kojong, vol. 34, year of 1897, 11th month, 22th day].

7 Kojongshillok. 5 kwŏn, Kojong 5 nyŏn yun 4 wŏl 10 il [Veritable Records of King Kojong, vol. 5, year of 1868, 4th leap month, 10th day]; Kojongshillok. 17 kwŏn, Kojong 17 nyŏn 1 wŏl 12 il [Veritable Records of King Kojong, vol. 17, year of 1880, 1st month, 12th day].

8 Chang, "Sŏyangin ŭi Kyŏnmun'gi rŭl t'onghae pon Myŏngsŏng Hwanghu," 11-15. 
and the role that she played - was similar to queens of the earlier Silla period, as a female governor who could exercise political power. On the other, she was different in that she was not invested with any officialinstitutionalized power to intervene; this was considered to be against her womanly 'nature' and contrary to her role as the spouse of a king. While it is contemptible that women had to learn to control and stifle their individual identities, history shows us that many were pushing at the limits of what was acceptable rather than fully succumbing to the traditional mores of the time.

However, what seems to be lacking in descriptions of Queen Min is how she anticipates in so many ways what we take to be contemporary woman's role and identity. This factor is crucial in appreciating the reasons why she provokes such interest. She was a woman who fought for the survival of her family line (the king and her son) and was a good wife who supported her husband by taking a clear position in the struggle between him and his father. She was also a heroine who sacrificed herself for the sake of her country. She was a woman who fought to be a free person to think and act in spite of the expectations of the time and her role. This profile of hers responds to that of a contemporary woman and this constitutes an important element in this article. Today's desire to give her a face responds to our contemporary need to match an identity to an image, and in a person therefore the superposition of an identity of person with the photo of her visual identity.

Working behind the scenes, Queen Min was a key figure in the takeover of power from her father-in law and securing it for King Kojong. Crucially, she managed to unite the whole Min clan, and also get the support of the regent's close relatives as well as that of Confucian scholars. There were several attempts on her life: there were explosions and a fire in the queen's apartments in Kyŏngbok Palace, after which Taewŏngun's servants were arrested. In 1874 she gave birth to a son, Prince Ch'ŏk (the last king of the Yi dynasty, Sunjong [純宗, r. 1907-1910]). Her antiJapanese policy was the reason why Miura Goro, the Japanese ambassador to Korea, decided to launch the so-called "Operation Fox Hunt" to 
assassinate her. Early in the morning of October $8^{\text {th }}, 1895$, a group of Japanese and Koreans attacked the queen's bedroom, dragging her out and killing her. Her body was taken into the forest beyond the palace walls where it was doused with kerosene and burned; the ashes were then scattered. ${ }^{9}$ Symbolically, this tragic end to her life also meant the death of the nation's hopes for independence and the growth of people's fears regarding an imminent Japanese invasion: subsequently, her close involvement in this disaster for the nation further obfuscated her identity, as will be discussed below.

Many descriptions of Min were provided by Westerners, adding much to our knowledge of her personality. Lilias Underwood, an American missionary who arrived in Korea in 1888, gave the following description of her appearance, her bearing and her attributes:

Slightly pale and quite thin, with somewhat sharp features and brilliant piercing eyes, she did not strike me at first sight as being beautiful, but no one could help reading force, intellect and strength of character in that face, and as she became engaged in conversation, vivacity, naivete, wit; all brightened her countenance, and gave it a wonderful charm, far greater than mere physical beauty; and I have seen the queen of Korea when she looked positively beautiful. [...] she possessed a very intelligent idea of the great nations of the world and their governments, $[\ldots]$ she was, moreover, a sovereign of broad and progressive policy, patriotic, and devoted to the best interests of her country. ${ }^{10}$

9 This Japanese-led assassination was reported by many foreign sources in Korea; see The Korean Repository (Seoul: Trilingual Press, 1892-1898). See also Sŏ Minkyo, "[Japanese Studies and Some Problems on the Assassination of Empress Myungseong]," Sach'ong [Sa-Chong] 59 (2004): 165-186.

10 Lilias Underwood, Fifteen Years among the Top-Knots (Boston: American Tract Society, 1904): 24. 
A vivid description was also provided by Annie Ellers Bunker, a missionary nurse who was able to meet the queen on several occasions. She left her first impressions in "My First Visit to Her Majesty the Queen" in The Korean Repository. ${ }^{11}$ Bunker's impressions are very positive: the queen is described as having a pleasant face, white skin, and she wears ornaments on her hairs. However, she is also a woman with a "strong will and great force of character, with a much kindliness of heart." 12 Indeed, these are the characteristics most often mentioned in the texts written by Westerners. ${ }^{13}$

The interest shown by Westerners and Koreans in the assassination of the queen is telling, and it underlines a common reading of the events. To murder a queen is an atrocious act in that it challenges the status quo; indeed, the details of her assassination glorified her memory, transforming her into a heroine and victim who was sacrificed in the name of brutal Japanese colonialism. Ultimately, we have an image of her in which her individual and historical identities blend. She is a woman consigned to posterity, but a woman who has no visual identity.

In the same 1895 volume of The Korean Repository, the article "The Assassination of The Queen of Korea"14 contains information and a description which are similar in content and style to what Carlo Rossetti wrote in his two-volume Corea e Coreani, published some years after the assassination, in 1904. ${ }^{15}$

Rossetti provides a detailed and lavish description of the assassination of the empress. In his book, Rossetti comments with great concern on the political developments in the peninsula: he considers the sad fate of Korea

11 Annie Ellers Bunker, "My First Visit to Her Majesty the Queen" in The Korean Repository, Oct. (1895): 373-375.

12 Ibid., 374.

13 Chang, "Sŏyangin ŭi Kyŏnmun'gi," 10-13.

14 The October and November issues of The Korean Repository of 1895 contain news, comments and a description of the queen and her assassination.

15 Carlo Rossetti, Corea e coreani, Impressioni e ricerche sull'Impero del Grande Han, 2 vols. (Bergamo: Istituto italiano d'Arti grafiche, 1904-1905). 
and harshly criticizes Japan for its political shortcomings. In the chapter "Japanese hegemony" he reports the dramatic death of the queen, stating that she was murdered in the most barbaric way in one of the palace rooms. Space is given over to Min in volume II, but it is in volume I, that Rossetti provides a detailed account of the political situation in the days leading up to the assassination, the court intrigues and the difficult relationship between the queen and her father-in-law. Rossetti sympathizes with the plight of King Kojong, saying that he is kept prisoner "if not openly, certainly in fact." King Kojong was to take refuge at the Russian Legation in Seoul, and Rossetti describes him kindly, referring to the "Poor Emperor!" or the "Misfortunes of the unhappy sovereign."16

In brief, the accounts of Queen Min evidence her private and public identities, and these details stimulate us to imagine what she actually looked like. This is compounded by her absence from photographs take of the royal family, of official events, or in the posed portraits that were popular at the time. The absence of her photo and portrait in official documents is paradoxically accompanied by the finding of several visual images of the queen in unofficial documents by non-Korean authors.

At this point, the questions are: why have certain photographs ended up being thought of as images of Queen Min, despite the fact that an actual photograph of her could never have existed? What was the function of the camera in the hands of foreigners in Korea at the turn of the $20^{\text {th }}$ century? Who took these photographs and what did they communicate? In order to answer these questions, it is first necessary to consider the context in which photographs circulated in this period, in particular with regard to those sold to foreigners.

What is important to notice is that the descriptions of Queen Min are helpful in getting a broader picture of her identity but are not particularly useful in identifying her as queen in one of the photographs. However, these are very useful in outlining her social and gender roles. Even more important is how the photographs - and how information - circulated 
among foreigners, which seems to suggest a metamorphosis of the queen's identity as it passed through various hands.

\section{The circulation of pictures of Korea and Koreans at the turn of the $20^{\text {th }}$ century}

In Korea as elsewhere, the development of modern visual systems is closely related to the development of printing, photography and the media. The history of photography in Korea is also distinguished by the fact that it is related to the history of Japanese colonialism: this means that on the one hand it was a tool used by the Japanese in their nationalistic policy of expansionism, and on the other it was a tool of modernity that future Koreans inherited, but that was still marked by this colonialist tradition. ${ }^{17}$

Photography was introduced to Korea in the early 1880s, and until 1907 it was in the hands of Japanese photographers who opened studios in Korea. With the legalization of residence rights for the Japanese in 1885, the first Japanese photographers such as Kaigunji, Ito and Fujita Shojaburo arrived in Korea. They photographed even the most remote regions and so their work became a source of information on Korean geography, customs and habits, which later became strategic material for military map drawing on the part of Japanese troops. In fact, the photographs from this period had a largely nationalistic and propagandist function (i.e., visual evidence of Japan's triumph over China and Japan as the bringer of modernization to Korea). ${ }^{18}$

17 Kwon Haengka, “Kŭndae sigakch'eche ŭi hyŏngsŏng kwachŏng: Ch'ŏngil chŏnchaeng ihu ilbonin sachinsa ŭi sachin hwaltong ŭl chungsimŭro [The Constitution of Modern Visuality in Korea: Focused on Works of Japanese Photographers around the Sino-Japanese War]," Hankuk Künhyŏndae Misul Sahak [Journal of Korean Modern \& Contemporary Art History] 26 (2013): 195-228.

18 Pak Chusŏk, "Chosŏnmal gwa taehanjeguk shigi sajin'girongmur ŭi sŏnggyŏk kwa saengsan, yut'ong kwajŏng [The Facets of Photographic Records on Korea in Modern Era]," Kirok'ak Yŏn'gu [The Korean Journal of Archival Studies] 62 
Of the Japanese imperial photographers active in Korea, Murakami Tensin (1867-?) should be mentioned for the purposes of the present paper. He resided in the country in the years when Queen Min was active in the political arena: he defined himself as the photographer of the Korean royal family and was responsible for many of the photographs that appear in the works of Rossetti and other Westerners. On the one hand, he provided visual material for Japan about events in Korea and thus played a very important role in paving the way for the invasion. On the other hand, he opened the Murakami Photography Studio, which soon became a place where Westerners visiting Korea could buy pictures for their collections. ${ }^{19}$

\section{Photography and identity}

Human beings use verbal and non-verbal languages to name and to conceptualize things and the self. Of non-verbal languages, visual image is one of the means that is closest to 'reality' as it resembles an 'eye', an extension of our own sight, using a technical medium that can immortalize a piece of 'reality' and capture it in time and place.

The desire for visual evidence of the queen's face was shared by contemporary Koreans, ${ }^{20}$ their interest fueled by the detailed description of her murder as well as by the mystery that surrounded her appearance. The existence of a possible painted portrait or photograph of her would go a long way towards solving the mystery of the queen's identity: moreover, a visual image, signifying "she is her", gives a face to this phase of the

(2019): 225-258.

19 See Pak, Chusŏk, "Ilcheha pukch'on ŭi sajin'gwan gwa $<$ kyŏngsŏngsajinsahyŏp'o $>$ eǔi tŭngjang [The Photostudio of Bukchon and $<$ Kyungseongsajinsahyuphoe $>$ during the Japanese Colonial Period]", Aura [Aura] 42 (2019): 61-73.

20 In fact, there was heated debate regarding the authenticity of several photographs thought to be of Queen Min, particularly in the 1990s. See Ŭn Chŏngt'ae, "Myŏngsŏng Wanghu Sajin Chinwi Nonjaeng [Dispute over the authenticity of alleged photographs of Queen Myŏngsŏng]", Yǒksa Bip'yŏng [Critical Review of History] Nov. (2001): 120-128. 
colonial and post-colonial history of Korea. It is not simply putting a face to a name; it implies an official historical recognition of a person's identity. As Min is a woman, it is also emblematic of gender in a specific social context (prior to Min there had been three other queens in the Silla period with full power to govern). The story of possible portraits of the queen that appeared over the years highlights the semantic function of the visual image; it is a means of conveying the reality that one wants to convey.

As mentioned above, however, history has not left a single image of Queen Min to posterity, although it has left us some photographs that present contradictory evidence. There has been much conjecture concerning the lack of a portrait of the queen. Some speculate that any possible photographs may have been deliberately destroyed after her death due to the political conflict in which she was involved. Others point to the absence of a tradition of portraiture or taking pictures of women in the court, particularly by Western photographers. It has also been suggested that Min was not photographed to protect her from danger.

The photographs that have at one time or another been attributed to the queen are listed below in chronological order:

1) In The Illustrated London News, 1894, July. ${ }^{21}$ The photograph is of a lady captioned "attendant on the King of Corea" and it was published in various newspapers entitled a "lady of the court."

2) The article "Le drame Coreen": Le reine de Coree - le Taï Wen Koun - le Roi Li Haï..., in the magazine L'illustration, 1895, by Raoul Villetard de Laguérie, who lived in Korea in 1895 (and was a war reporter during the Sino-Japanese War) contains a photograph with the caption "La Reine del Corée". ${ }^{22}$

3) In the book entitled La Corée, Indépendante, Russe, ou Japonaise

21 The Illustrated London News, Saturday July 28 (London: William Little, 1894): 4.

22 Raoul Villetard de Laguérie, ““'Le Drame Coreen”: le reine de coree - le Taï Wen Koun - le Roi Li Haï. Portrait et dramatique histoire racontée par Villetard de Laguérie," L'Illustration 2749 (1895): 6. 
by the same author as no. 2. On the cover of the book is a picture of the royal family: the king, the queen and her father-in-law. The same pictures, in larger size, are found on pp. 12, 13. The image of the queen is the same as in no. $2 .^{23}$

4) In Rossetti's Corea e Coreani, Impressioni e ricerche sull'Impero del Grande Han, Part II, 1904, p. 99, there is a picture of a lady with the caption "A palace lady in court dress". ${ }^{24}$

5) Rossetti's photograph is the same as the one found in the book With Tommy Tompkins in Korea (1905), p. 292, accompanied by the caption "A Korean lady in full costume". The author of the book is Lillias Underwood, wife of Horace Grant Underwood: she served as personal physician to Queen Min. ${ }^{25}$

6) in The Passing of Korea, New York: Doubleday, 1906, Chapter IX "The Assassination of the Queen", p. 139, written by H. B. Hulbert, who was King Kojong's political advisor. This contains the same photograph mentioned in nos. 4 and 5 and bears the caption "The Palace Woman in full regalia". ${ }^{26}$

7) The Spirit of Independence by the first Korean president, Syngman Rhee and written in 1904 contains a picture of a lady who is indicated as "the Empress Myŏngsŏng", ${ }^{27}$

23 Raoul Villetard de Laguérie, La Corée, Indépendante, Russe, ou Japonaise. D'après des photographies (Paris: Librairie Hachette et C, 1898): 12.

24 Rossetti, Corea e Coreani, vol. II: 99.

25 Lillias Underwood, With Tommy Tompkins in Korea (New York: Fleming H. Revell Company, 1905): 292.

26 Homer Hulbert, Passing of Korea (London: William Heinemann, 1906): 139.

27 Rhee, Syngman, Tongnip chyŏngshin [The Spirit of Independence] (Los Angeles: Taedongshinsŏgwan, 1910): 263. 


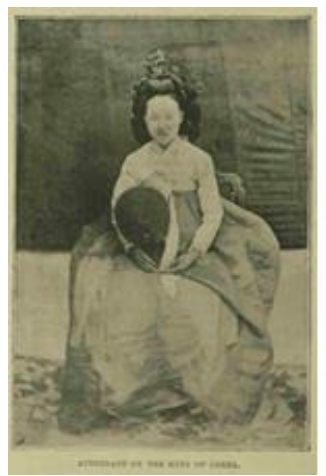

[No. 1]

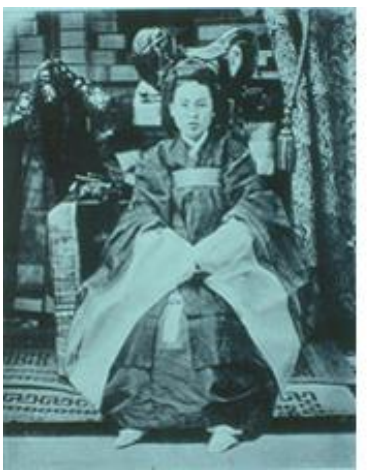

[No. 4]

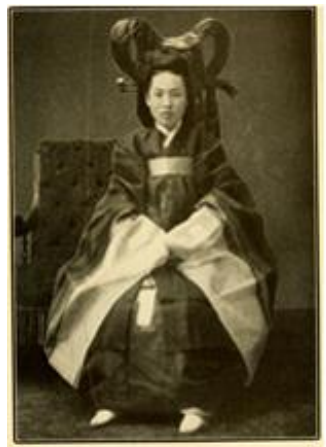

[No. 5]

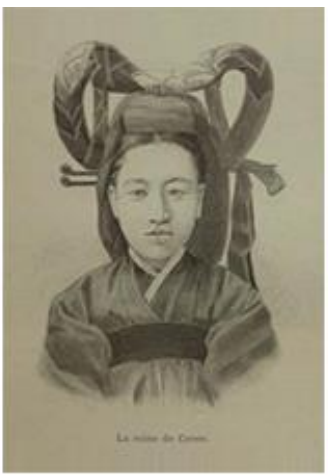

[No. 2]

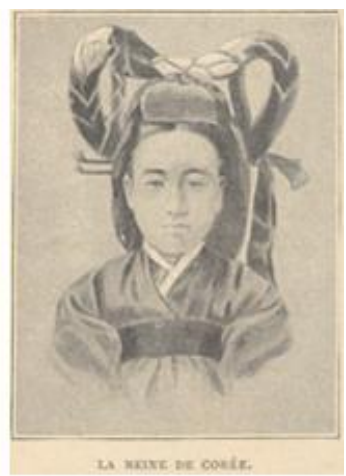

[No. 3]

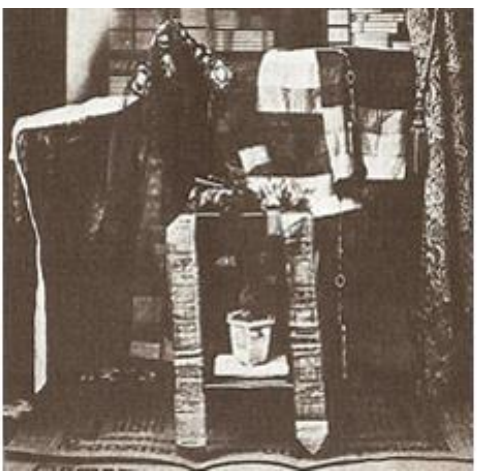

"The wardrobe of ghi-sang" in Rossetti (1904), 111.

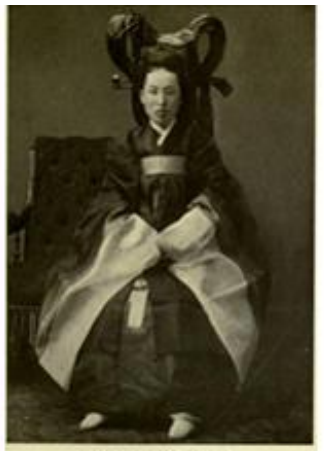

[No. 6]

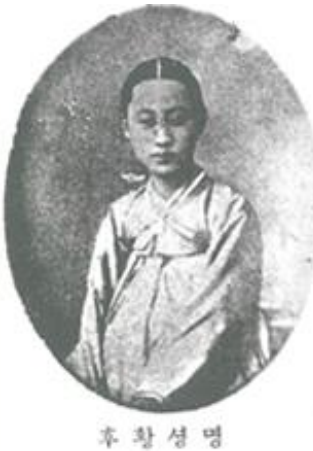

[No. 7] 
This list merits some further considerations. Although photographs no. 5 (Underwood, 1905, the same or similar to no. 4) and no. 7 (Syngman Rhee, 1910) were those that were generally found in Korean secondary school history books up until a few years ago, they have now been discredited by historians. ${ }^{28}$ The lady in no. 4,5 and 6 is not wearing shoes (something that would not be acceptable for an empress and even less so for a photographic session), and her dress is also not that of an empress. The facial expression in no. 1 is also not suitable for an empress, who would have been taught from a very early age that her face must lack expressiveness. Moreover, the lady in no. 7 is wearing an ordinary dress to pose in front of a photographer, something that would not be fitting for a queen; furthermore, the testimonies of those who lived with the queen deny that the woman in the photograph is Min. ${ }^{29}$

In brief: the women in nos. 2, 3, 4, 5 and 6 look very similar, although only nos. 2 and 3 claim to be photographs of the queen. Photograph no. 7 is said to be of the empress, but this was discredited by witnesses who knew Queen Min. No. 1 is different from all the other pictures mentioned and is described as being "attendant on the King of Corea" or a "lady of the court'. From the chronological point of view, the women portrayed look very similar in 1895 and 1898 (nos. 2 and 3), 1904 (no. 4), 1905 (no. 5) and 1906 (no. 6).

The very backgrounds of the photographs provide a further means of analysis with regard to intertextuality or photomontage. Photograph no. 4 has a background (a bookcase, some clothing accessories, a western curtain with drapery, a carpet) that is different to the background seen in 5 and 6 (an overstuffed western armchair, perhaps dark in color; photograph 6 looks like a copy of 5 and both resemble 4 with some changes to the background), and 2 and 3 (a half-length portrait with no background). Looking closely at photograph no. 4 and comparing it with another one in

28 Ǔn, “Myŏngsŏng Wanghu Sajin”, 124-125.

29 Ibid. See also Sin, Pokyong, "Myŏngsŏng Wanghu ŭi Ch'osang [The Portrait of Empress Myŏngsŏng],” Tongailbo [Dong-A Ilbo], July 6st 2001. 
the same book on page 115, with the caption "The wardrobe of a $g h i$ sang", we note that the background is identical and that you can see the bookcase, a curtain to one side, other items of women's clothing, and a carpet. This suggests that both photographs were taken in the same place and perhaps even at similar times. Moreover, other posed photographs in Corea e Coreani also suggest that this is a studio set up for formal portraits.

Photographs nos. 4, 5 and 6 suggest that there was an exchange of information and photographs between foreigners who were living in Korea. Among collectable objects, pictures of the royal family must have been extremely attractive to buy and share when exchanging news about Korea.

Picture no. 7 is interesting due to the fact that the face portrait is very similar to the posed portrait of the lady wearing gloves in Chosŏn Kisaeng Sajinch'ŏp (1894) who is described as a 'kisaeng'. The only difference is that the kisaeng is sitting in an elegant pose and is wearing gloves, which was a point of etiquette limited to women of the royal family. Thus, the fact that the lady is indicated as a kisaeng and her portrait is included in a magazine for kisaeng only adds to the mystery of her identity.

On the other hand, it is interesting that there are several additional references dating from the 1930s that indicate the existence - or not - of a painted portrait or photograph of Queen Myŏngsŏng. First, the July 1930 issue of Samch'ólli included a photograph claiming to be Queen Min, which is identical to the aforementioned picture no. $7 .{ }^{30}$ In addition, according to an article in Chosŏnilbo written by Mun Ilp'yŏng in 1934, Emperor Kojong recalled that a portrait of the queen had once been commissioned: indeed, he offered a reward for it to be found, but to no avail. ${ }^{31}$ In contrast, a 1933 article of Samch'ólli tells us that no one saw the face of

30 Ch'o Sa, "Ilserŭl Kyŏngdong Shik'idŏn Koegŏl, Yi Yongik Ssi ŭi 90 manwŏn sagŏn [The robbery of 900 thousand won and Mr. Yi Yongik that astonished the world]," Samch'ölli [Threethousand Ri] 7 (July 1930): 18.

31 Chosŏnilbo [Chosun Ilbo], March 2nd 1934, appendix: 3. 
the last Chosŏn queen. ${ }^{32}$

Therefore, we must conclude that all these reports, unfortunately, provide us with no conclusive evidence of the existence of an actual photograph or a painted portrait. As mentioned above, from the 1880s Japanese photographers came to Chosŏn and sold various photographs to Westerners in major cities like Kyŏngsŏng, Inch'ŏn and Pusan. Considering that photographers or sellers were not proficient in foreign languages, there may have been some misunderstanding, or even intentional misinformation given, about the subject of the photographs that they sold. In other words, it is highly likely that sellers might have been claimed that the same photograph was of a court lady or of the queen herself. ${ }^{33}$ While the narrative in the search for a photo of the queen confirms the absence of this in official documents, one wonders about the meaning of the words expressed by the emperor in claiming that a portrait of the empress was commissioned. The failure to find her portrait leads us to wonder whether women of the royal family and of the aristocracy were forbidden from having their portraits taken. In doing so, we can place any such absence of a visual identity of the queen in its historical context.

\section{Women's portraits in the Chosŏn dynasty}

The first half of the Chosŏn dynasty

There is a variety of records regarding the portraits of women painted in the first half of the Chosŏn dynasty. In fact, producing portraits of the king and queen was a well-established tradition in the early Chosŏn period. The practice had originated in the preceding Koryŏ dynasty: the court commissioned and enshrined pictures of successive kings and queens, as we can see from the painting of King Kongmin (恭䬳王, 1300-1374, r.

32 “Min Pi [Queen Min]," Samch'ólli 5.9 (September 1933): 65

33 Pak, "Chosŏn mal gwa Taehan jeguk shigi sajin," 243-246. 
1351-1374) and Queen Noguk (魯國大長公主, ?-1365), which was part of the funeral rites for deceased royalty. ${ }^{34}$ It seems that the Chosŏn court maintained this tradition in its earlier years. For instance, in 1398 King Taejo (太祖, 1335-1408, r. 1392-1398) held a memorial service for his consort Queen Shinŭi (神懿王后, 1337-1391) with a painting of her, ${ }^{35}$ thus continuing the Koryŏ tradition.

The practice of producing portraits of royal women continued during the first half of the Chosonn period. In fact, there are several records that clearly indicate the existence of portraits of queens: in 1443 King Sejong (世宗, 1397-1450, r. 1418-1450) commissioned a group of painters to produce a portrait of his consort, Queen Sohŏn (昭憲王后, 1395-1446). ${ }^{36}$ In addition to this, a picture of Queen Chŏnghŭi (貞喜王后, 1418-1483), consort of King Sejo (世祖, 1417-1468, r. 1455-1468) and grandmother of King Sŏngjong (成宗, 1457-1495, r. 1469-1494), was brought by royal order into the royal palace in $1472 .{ }^{37}$ Moreover, a series of portraits of queens were produced and reproduced in the early years of the Chosonn dynasty right up to the reign of King Chungjong (中宗, 1488-1544, r. 1506-1544). ${ }^{38}$ In short, as clearly stated in the reign of King Injong (仁宗, $1515-1545$, r. 1544-1545), who in 1545 ordered that the production of

34 On the paintings of King Kongmin and Queen Noguk and the portrait tradition of Koryŏ, see Kang, Myǒng-gwan, Kŭrim ŭro ingnŭn Chosŏn yŏsŏng ŭi yŏksa [Women's History in Chosŏn Korea as Viewed through Paintings] (Seoul: Humanist, 2012): 20-27.

35 "A new portrait painting of Queen Shinŭi was enshrined at Insojŏn and the king in person performed the commemorative rites for the deceased queen (安神懿王后新畫于仁昭殿, 親幸行祭).” T'aejoshillok, 15 kwŏn, T'aejo 7 nyŏn 12 wŏl 25 il [Veritable Records of King T'aejo, vol. 15, year of 1398, 12th month, 25th day].

36 Sejongshillok, 106 kwŏn, Sejong 26 nyŏn 10 wŏl 22 il [Veritable Records of King Sejong, vol. 106, year of 1444, 10th month, 22nd day]

37 Sŏngchongshillok, 18 kwŏn, Sŏngchong 3 nyŏn 5 wŏl 19 il [Veritable Records of King Sŏngchong, vol. 18, year of 1472, 5th month, 19th day].

38 Cho, Sŏnmi, Han'guk Ch'osanghwa Yŏn'gu [Study on Korean Portraits] (Seoul: Yŏrhwadang, 1983): 358-360; Kang, Chosŏn yŏsŏng ŭi yŏksa, 45-48. 
portraits of the late King Chungjong should cease, "there were always the portrait paintings of preceding kings and queens for ancestral ceremonies". 39

Furthermore, the Koryŏ tradition of making husband and wife portraits was still popular among the noble classes (土大夫), of which there are several examples. The first portrayed the wife of Cho Pan (趙胖, 13411401), one of the founding supporters (開國功臣) of the Chosŏn dynasty, which was painted alongside that of a separate portrait of her husband. There are portraits of two more noble women, the wife of Ha Yŏn (河演, 1376-1453) and the wife of Pak Yŏn (朴堧, 1378-1453), whose husband held government posts during the reign of King Sejong. The picture of the Ha Yŏn was accompanied by a separate portrait of his wife, while Pak Yŏn was portrayed next to his wife as in the portrait of King Kongmin and Queen Noguk of the Koryŏ dynasty. This kind of portrait painting was also produced in the later years, as we can see from the picture of Chŏng Sik (鄭軾, 1407-1469) and his wife. From these examples, it can be concluded that in the early years of the Chosorn dynasty there was a well-established practice among the nobility of producing portrait paintings of husband and wife, and this was a popular tradition that had survived from the earlier dynasty. ${ }^{40}$ In addition to this, there are references to portraits being painted of woman up to the end of the $16^{\text {th }}$ century. For example, Cho Ǔnggyŏng (趙應卿, 1487-1579), grandson of Cho Ryŏ (趙 旅, 1420-1498) who withdrew from his government position after the coup d'état of King Sejo (癸西靖難, 1453), wanted to have a portrait painted of his parents who had both passed away in his twenties. ${ }^{41}$

39 “...故先王、先后影幀, 無世無之...” Injongshillok 1 kwŏn, Injong 1 nyŏn 1 wŏl 22 il [Veritable Records of King Injong, vol. 1, year of 1545, 1st month, 22nd day]. 40 Cho, Ch'osanghwa Yŏn'gu, 365-366; Kang, Chosŏn yŏsŏng ŭi yŏksa, 51-58.

41 Ibid. 
The second half of the Chosŏn dynasty

Interestingly, it seems that Chosŏn society abandoned the tradition of painting women's portraits for a specific reason about the time of the Japanese invasions of Chosŏn that started in 1592. For example, references to portraits of women almost completely disappeared in the Veritable Records. Additionally, it seems that portraits of noblewomen were only produced up to the end of the $16^{\text {th }}$ century. ${ }^{42}$ Indeed, the practice of depicting women on canvas faded away almost completely in the second half of the Chosŏn dynasty.

The main reason for this phenomenon was the assimilation of the principles of Confucianism, which were adopted into Chosŏn society as the ruling ideology of the dynasty. First of all, regarding ancestor rites, spirit tablets (位牌) were to be considered objects of Confucian rituals rather than portraits, which had been used in the Buddhist tradition of the earlier dynasty. ${ }^{43}$ Indeed, although the aforementioned Koryŏ tradition of ancestor rites with portraits continued in the early years, the Chosŏn court also made use of spirit tablets in ancestral rituals. In 1408, for instance, in the presence of King T'aejong (太宗, 1367-1422, r. 1400-1418), it was said that according to the Book of Rites (禮經), spirit tablets should be the object of ancestor rites, although the tradition of worshipping the portraits of ancestors could be maintained. ${ }^{44}$ In other words, spirit tablets were already substituting the function of portraits in ancestral ritual formalities even in the early Chosŏn period.

As Confucianism became well established in the second half of the Chosŏn dynasty, commissioning portrait paintings of ancestors for ritual

42 Ibid.

43 On ancestral rituals in the Chosŏn dynasty, see Son, Myenghee, Like Life: Royal Portraits of the Joseon Dynasty (1392-1910) in Ritual Context, Ph.D. Dissertation, University of Kansas, 2018: 23-62.

44 T'aejongshillok, 16 kwŏn, T'aejong 8 nyŏn 8 wŏl 7 il [Veritable Records of King T'aejong, vol. 16, year of 1408, 8th month, 7th day]. 
purposes started to be considered heterodox according to Confucian ancestral ritual formalities. ${ }^{45}$ The portraits of kings and queens were no exception, ${ }^{46}$ not to mention those of the noble class (or yangban). However, the court maintained the tradition of commissioning the portraits of kings in the later Chosŏn period, ${ }^{47}$ especially from the reign of the King Sukchong (肅宗, 1661-1720, r. 1674-1720). ${ }^{48}$

It is therefore reasonable to assume that there might have been another reason why kings' consorts were no longer the subjects of portraits. In this respect, it is necessary to examine how women were seen within the framework of the patriarchal ideology of Confucianism. ${ }^{49}$ In this light, women were not independent individuals, but subordinate to male family members. They were to devote themselves purely to domestic affairs and

45 From a Confucian point of view, the portraits for ancestral ceremonies had to look exactly like the subject. If not, there might be risk of the ancestry rites being addressed to a different person. Cf. Kang, Chosŏn yŏsŏng ŭi yŏksa, 57-63.

46 Lee, Kangkŭn, “Chosŏn hugi Sŏnwŏnjŏn ŭi kinŭng gwa pyŏnch'ŏn e kwanhan yŏn'gu [The Structural Transformation of the Main Hall of Seonwonjeon Complex of Joseon Dynasty and its Significance]," Kangjwa Misulsa [The Art History Journal] 35 (2010): 239-268.

47 It is assumed that the Chosŏn court commissioned posthumous royal portraits starting with King Tŏkchong (德宗, 1438-1457), father of King Sŏngjong. Myŏngjongshillonk, 8 kwŏn Myŏngjong 3 nyŏn 10 wŏl 10 il [Veritable Records of King Myŏngjong, vol. 8, year of 1548, 10th month, 10th day]. See also Son, Myenghee, "Sejo ŏjin ŭi tu ponganch'ŏ [Two Places of Worship Enshrining Portraits of King Sejo]," Han'guk Munhwa [Korean Culture] 93 (2021): 277-304.

48 In the second half of the Chosŏn dynasty, King Sukchong was the first king to commission portraits of himself during his lifetime. On portraits of the king painted in his reign, see Lee, Sŏnghun, "Sukchong gwa Sukchong ŏjin ŭi Chejak kwa Pongan [A Study of the Production and Enshrinement of King Sukjong's Portraits]," Misulsa wa Sikak Munhwa [Art History and Visual Culture] 24 (2019): 2471.

49 For a general introduction to the Confucian view of woman focusing on the thoughts of Yulgok, see Ch'oe, Yŏngjin, "Chosŏnsitae yukyo ŭi yŏsŏngkwan [Confucian View on Woman in Chosŏn Period]," Hankuk Sasangsahak [Korean History of Thoughts] 20 (2003): 1-15. 
were prohibited from any contact with men outside the family. As a result, Chosŏn women were confined to the house, ${ }^{50}$ especially if they were queens or women of the highest status in society.

In this scenario, a dispute regarding a portrait of queen in the reign of King Sukchong provides an interesting example. In 1695, after commissioning several portraits of himself, the king made an attempt to have Queen Inhyŏn (仁顯王后, 1667-1701), his second consort, painted. ${ }^{51}$ The king's wishes were thwarted because of the sustained opposition of his subjects. According to the Veritable Records, they thought that the portrait was to be of his deceased queen rather than the one that was still alive. When the king made his intentions clearer, his subjects opposed the idea even more strongly, saying that not only was it without precedent in the whole history of the dynasty, but that it was also not in accordance with Confucian principles. ${ }^{52}$

In addition, we should mention those to whom King Sukchong assigned the commission. First, he nominated Yi Hon (臨昌君 李焜, 16631725) and Kim Jin'gyu (金鎭圭, 1658-1716) to create his consort's portrait: the former was a member of royal family, while the latter was not only a well-known painter of the time, but also the brother of the king's first consort, Queen In'gyŏng (仁敬王后, 1661-1680). ${ }^{53}$ After receiving a series of negative reactions from his subjects, the king ordered the current queen's brother to accompany her while the painting was carried out: according to court etiquette, the queen could not be alone when posing for a portrait. That is, the queen's portrait could be painted only if there were female painters in the court, as the king stated, ${ }^{54}$ or if it was painted by

50 Kang, Chosŏn yŏsŏng ŭi yŏksa, 35-42.

51 Sukchongshillok. 29 kwŏn, Sukchong 21 nyŏn 7 wŏl 27 il [Veritable Records of King Sukchong, vol. 21, year of 1695, 7th month, 27th day].

52 From this we can assume that producing a royal portrait after the subject had passed away was an actual practice in the second half of the Chosŏn dynasty.

53 This could be another reason why his subjects presumed the king's intention was to produce a portrait of the deceased queen.

54 King Sukchong clearly said that there were no women who could paint a portrait 
one of her relatives. In the end, the king's plan failed and henceforth there were no more portraits of queens produced until the end of the dynasty.

In the second half of Chosŏn dynasty, the custom of portraying women could only be justified when it coincided with Confucian principles, such as making portraits of beautiful or virtuous women: in the first case the portraits might be appreciated by men of the noble classes, while the latter were an effective means of conveying the ideal image of women from a Confucian perspective. ${ }^{55}$ For example, a portrait of a noble woman was discovered in 2004: the funeral portrait of Lady Oh of Pokch'ŏn (福川 吳 夫人, 1676- 1761?), wife of Yi Chik (密昌君 李樴, 1677-1746). ${ }^{56}$ It dates from 1761 when the subject was 86 years old and it was painted by Kang Sehwang (姜世晃, 1713-1791), a renowned painter of the time. It is assumed that her son Yi Ikchŏng (李益炡, 1699-1782) commissioned the portrait for his mother's $86^{\text {th }}$ birthday celebrations. ${ }^{57}$ The son could justi-

of the queen in the palace: "...it is unusual that there has been a good female painter in the court... (...其時必無女人之工畫者...)” Sukchongshillok. 29 kwŏn, Sukchong 21 nyŏn 7 wŏl 27 il [Veritable Records of King Sukchong, vol. 21, year of 1695,7 th month, 27th day].

55 However, since these beautiful or virtuous women were anonymous, it is difficult to include these paintings in the same category as portraits. On pictures of beautiful women, see Pak, Yŏngmin, "Chosŏnshida eŭi Miindo wa Yŏsŏng Ch'osanghwa tok'ae rŭl wihan cheŏn [A Study on Joseon Miindo and Woman Portraits]," Hanmunhaknonchip [Journal of Korean Literature in Chinese] 42 (2015): 41-75. On paintings of virtuous women, see Shin, Sugyŏng, "Yŏllyŏjŏn gwa Yŏllyŏdo ŭi Imiji Yŏn'gu [Lienu Zhuan and Lienu Picture's Image]," Misulsanondan [Art History Forum] 21 (2005): 171-200; Sin, Sugyŏng, "Chosŏnshidae Yŏllyŏdoŭi Yangt'aewa Yŏllyǒsŏssip'ojukto [The Spread of Paintings of Virtuous Women in the Joseon Dynasty and Virtuous Lady Seo Embracing Bamboos]," Misulsahakyŏn'gu [Korean Journal of Art History] 253 (2007): 129-158. On the relationship between this type of painting of women and beautiful women and Confucianism, see Kang, Chosŏn yŏsŏng ŭi yŏksa, 64-104.

56 Yun Chinyoung, "Kang Sehwang Chak $<$ Pokch'ŏn Oh buin Yŏngjŏng $>$ [Bokchoen Lady Oh's portrait scroll by Kang Se-hwang]," Kangjwa Misulsa [The Misulsa], 27 (2006): 259-284.

57 Ibid., 270-272. 
fy his decision to have his mother's portrait painted, because she was extraordinarily long-lived, and a model mother according to Confucian ideology.

The tradition of producing portraits of women thus disappeared in the second half of the Chosonn period. Firstly, according to the Veritable Records, there is no evidence indicating the commissioning of portraits of queens until the end of the dynasty, even though the court commissioned portraits of kings at various times. As we can clearly see in the case of Queen Inhyŏn, even queens were no exception to Confucian views on women; indeed, the rule had to be applied more strictly than usual. ${ }^{58}$ In other words, noble women of the Chosŏn dynasty, queens included, were to be confined to the house without any contact with men except those in their family. This continued for as long as the Confucian view on women held sway, that is, until the $19^{\text {th }}$ century, ${ }^{59}$ ensuring that women were subordinate to men and that the former had no contacts outside the family. Furthermore, Confucian ideology did allow a few women to be the subjects of portraits: an aging mother could be celebrated, a beautiful woman appreciated or a virtuous one admired. In short, portraits of women were extremely rare in the later Chosŏn period.

It is therefore not surprising that the first record of a portrait painted of a queen in the Chosŏn dynasty after the reign of King Sukchong appears about 200 years later, in 1900. This is when the Chosŏn kingdom came to an end and the Korean Empire was proclaimed. The queen in question was obviously Queen Min and we can find four references to a picture of

58 For example, in the reign of King Chungjong, when the portraits of the king and Queen Chŏngan had to be verified as genuine, only the current prince was allowed to see the painting of the queen. Chungjongshillok, 94 kwŏn, Chungjong 35 nyŏn 10 wŏl 10 il [Veritable Records of King Chungjong, vol. 94, year of 1540, 10th month, 10th day]: “...王后御容, 則外提調, 不可見也，故令王子君奉審也...”

59 Kim, Ŏnsun, "Kaehwaki yŏsŏng kyoyuk e naechaetoen yukyochŏk yŏsŏngkwan [Confucian Views of Women Inherent in Women's Education, in Early Modern Period]," P'eminijŭm yŏn'gu [Issues in Feminism] 10.2 (2010): 35-87. 
the deceased, all in the Veritable Records of King Kojong's reign. ${ }^{60}$ Interestingly, whenever the emperor expressed his intention to see a portrait of his deceased consort, he explicitly mentioned "the original picture from which the portrait for the funeral was made." These references thus indicate that there must have been an original picture from which the court commissioned a portrait for the queen's obsequies. At the same time, this also means that there remains a doubt as to whether the picture was created while she was alive, especially if we consider the aforementioned limitations on commissioning women's portraits in the Chosŏn period.

\section{Concluding remarks}

Although still far from being able to claim the visual identity of Queen Min from among those mentioned, the present article has nevertheless identified the chronology of the extant photographs. While the basic con-

60 Kojongshillok, 40 kwŏn Kojong 37 nyŏn 5 wŏl 1 il [Veritable Records of King Kojong, vol. 40, year of 1900, 5th month, 1st day]: “...the emperor says: tomorrow, I will pay a visit to the Hŭngdŏkchŏn and see the original picture (of queen) with which was created the portrait for the funeral (... 又詔曰: "明日當詣興德殿展謁後, 移摹影幀初本奉審矣...).”; Kojongshillok, 40 kwŏn Kojong 37 nyŏn 11 wŏl 30 il [Veritable Records of King Kojong, vol. 40, year of 1900, 11th month, 30th day]: "...the emperor says: the day after tomorrow, after the royal ancestral ceremony at Hŭngdŏkchŏn, I will see the original picture with which was created the portrait for the funeral (...詔曰: "再明日興德殿酾裋後, 移摹影幀初本奉審矣...)”; Kojongshillok, 40 kwŏn Kojong 37 nyŏn 12 wŏl 25 il [Veritable Records of King Kojong, vol. 40, year of 1900, 12th month, 25th day]: “...The emperor says: the day after tomorrow, I will visit Hŭngdŏkchŏn and see the original picture with which was created the portrait for the funeral (...詔曰: "再明日當自內, 詣興德殿, 展謁後, 移摹影幀初本奉審矣...”; Kojongshillok, 40 kwŏn Kojong 38 nyŏn 1 wŏl 20 il [Veritable Records of King Kojong, vol. 40, year of 1901, 1st month, 20th day]: "The emperor says: the day after tomorrow, I will go to see the original picture with which was created the portrait for the funeral (詔曰: "再明日...移摹影幀初本, 奉審矣....” 
cept of identity implies equality, equality between two things or people (i.e., $\mathrm{A}=\mathrm{A}$ ), we can make three hypotheses regarding the identity of the photographs: queen, court lady, and kisaeng. These hypotheses are based on the fact that the first two terms were used by Westerners, while the other term was used provably by Japanese, according to Koreans. There is no overlap between these two groups (i.e., Westerners indicated similar pictures as queen or court lady, while non-Westerners indicated kisaeng). Further analysis shows that the issues regarding any possible identification of the pictures are extremely complex.

The absence of an image of the queen led the article to question whether there was a tradition in the past of not displaying a noblewoman's face. The article has therefore discussed the tradition of photographs or portraits of women in the period prior to Queen Min. It does not seem plausible to accept that women were not portrayed in earlier times (although Confucianism strongly discouraged this) or between the late $19^{\text {th }}$ and early $20^{\text {th }}$ century (given the existence of photographic studios, including those for women only). ${ }^{61}$ Ultimately, questions regarding the absence of the Queen Min's visual identity remain to this day and will remain. However, the intent of the present paper has been to highlight how this absence contributes to the blurring of the Min's identity both as an individual and as a historical figure.

\section{References}

Primary Sources

1. Chosŏnilbo. 朝鮮日報.

2. Chosŏnwangjoshillok. 朝鮮王朝實錄.

61 Lee, Kyungmin, "The Development of Photo Studios in Korea," Trans-Asia Photography 4.2 (2014), trans. Jeehey Kim, published originally, in Korean, in Hwanghae Munhwa [Hwanghae Review] 51 (2006): 315-323. 
3. L'Illustration.

4. Samch'ǒlli. 三千里.

5. The Illustrated London News.

6. The Korean Repository.

7. Hulbert, Homer. Passing of Korea. London: William Heinemann, 1906.

8. Laguérie, Raoul Villetard de. La Corée Indépendante, Russe, ou Japonaise. D'après des photographies. Paris: Librairie Hachette et C, 1898.

9. Rhee, Syngman. Tongnip chyŏngshin [The Spirit of Independence]. Los Angeles: Taedongshinsŏgwan, 1910.

10. Rossetti, Carlo. Corea e coreani, Impressioni e ricerche sull'Impero del Grande Han, 2 vols. Bergamo: Istituto italiano d'Arti grafiche, 1904-1905.

11. Tongailbo. 東亞日報

12. Underwood, Lilias. Fifteen Years among the Top-Knots. Boston: American Tract Society, 1904.

13. With Tommy Tompkins in Korea. New York: Fleming H. Revell Company, 1905.

\section{Secondary Sources}

14. Cho, Sŏnmi. Han'guk Ch'osanghwa Yŏn'gu [Study on Korean Portraits]. Seoul: Yŏrhwadang, 1983.

15. Ch'oe, Yŏngjin, "Chosŏnsitae yukyo ŭi yŏsŏngkwan [Confucian View on Woman in Chosŏn Period]," Hankuksasangsahak [Korean History of Thoughts] 20 (2003): 1-15.

16. Chang Yŏngsuk, “Sŏyangin ŭi Kyŏnmun'gi rŭl t'onghae pon Myŏngsŏng Hwanghu ŭi chŏngch'ijŏk wisang gwa Yŏk'al [The Political Status and the role of Empress Myeongseong Hwanghu - As Examined from the Travel Records of the Westerners -]," Han'guk Künhyŏndaesa Yŏn'gu [Journal of Korean Modern and Contemporary History] 35 (2005): 7-31. 
17. Kang, Myǒng-gwan. Kŭrim ŭro ingnŭn Chosŏn yŏsŏng ŭi yŏksa [Women's History in Chosŏn Korea as Viewed through Paintings]. Seoul: Humanist, 2012.

18. Kim, Ŏnsun. "Kaehwaki yŏsŏng kyoyuk e naechaetoen yukyochŏk yŏsŏngkwan [Confucian Views of Women Inherent in Women's Education, in Early Modern Period]," P'eminijŭm yŏn'gu [Issues in Feminism] 10.2 (2010): 35-87.

19. Kwon Haengka. "Myŏngsŏng Hwanghu wa Kungmo ŭi P'yosang [Reperesentation of Empress Myeongseong as the Mother of the Nation]," Misulsa Yŏn'gu [Journal of Art History] 21 (2007): 203-230.

20 . . “Kŭndae sigakch'eche ŭi hyŏngsŏng kwachŏng: Ch’ŏngil chŏnchaeng ihu ilbonin sachinsa ŭi sachin hwaltong ŭl chungsimŭro [The Constitution of Modern Visuality in Korea: Focused on Works of Japanese Photographers around the Sino-Japanese War]," Hankuk Künhyŏndae Misul Sahak [Journal of Korean Modern \& Contemporary Art History] 26 (2013): 195-228.

21. Lee, Kangkŭn. "Chosŏn hugi Sŏnwŏnjŏn ŭi kinŭng gwa pyŏnch'ŏn e kwanhan yŏn'gu [The Structural Transformation of the Main Hall of Seonwonjeon Complex of Joseon Dynasty and its Significance]," Kangjwa Misulsa [The Art History Journal] 35 (2010): 239-268.

22. Lee, Kyungmin. "The Development of Photo Studios in Korea," Trans-Asia Photography 4.2 (2014). trans. Jeehey Kim. published originally in Korean, in Hwanghae Munhwa [Hwanghae Review] 51 (2006): 315-323.

23. Lee, Sŏnghun. "Sukchong gwa Sukchong ŏjin ŭi Chejak kwa Pongan [A Study of the Production and Enshrinement of King Sukjong's Portraits]," Misulsa wa Sikak Munhwa [Art History and Visul Culture] 24 (2019): 24-71.

24. Pak, Chusŏk. "Chosŏn mal gwa Taehan jeguk shigi sajin' girongmul ŭi sŏnggyŏk kwa saengsan, yut'ong kwajŏng [The Facets of Photographic Records on Korea in Modern Era]," Kirok'ak Yŏn'gu [The Korean Journal of Archival Studies] 62 (2019): 225-258.

25. . "Ilcheha pukch'on ŭi sajin'gwan gwa <kyŏngsŏng- 
sajinsahyŏp'o $>$ eŭi tŭngjang [The Photostudio of Bukchon and <Kyungseongsajinsahyuphoe> during the Japanese Colonial Period]", Aura [Aura] 42 (2019): 61-73.

26. Pak, Yŏngmin. "Chosŏnshida eŭi Miindo wa Yŏsŏng Ch'osanghwa tok'ae rŭl wihan cheŏn [A Study on Joseon Miindo and Woman Portraits]," Hanmunhaknonchip [Journal of Korean Literature in Chinese] 42 (2015): 41-75.

27. Serpe, Richard T and Stets Jan E. "Identity Theory," in Handbook of Social Psychology. Edited by John DeLamater and Amanda Ward. Dordrecht: Springer, 2013, 31-60.

28. Sin, Sugyŏng. "Yŏllyŏjŏn gwa Yŏllyŏdo ŭi Imiji Yŏn'gu [Lienu Zhuan and Lienu Picture's Image]," Misulsanondan [Art History Forum] 21 (2005): 171-200.

29. . “Chosŏnshidae Yŏllyŏdoŭi Yangt'aewa Yŏllyŏsŏssip'ojukto [The Spread of Paintings of Virtuous Women in the Joseon Dynasty and Virtuous Lady Seo Embracing Bamboos]," Misulsahakyŏn'gu [Korean Journal of Art History] 253 (2007): 129-158.

30. Son, Myenghee. Like Life: Royal Portraits of the Joseon Dynasty (1392-1910) in Ritual Context. Ph.D. Dissertation. University of Kansas, 2018.

31. . "Sejo ŏjin ŭi tu ponganch'ŏ [Two Places of Worship Enshrining Portraits of King Sejo]," Han'guk Munhwa [Korean Culture] 93 (2021): 277-304.

32. Sŏ Minkyo, "[Japanese Studies and Some Problems on the Assassination of Empress Myungseong]," Sach'ong [Sa-Chong] 59 (2004): 165-186.

33. Sŏ Yŏnghŭi. "Myŏngsŏng Hwanghu Yŏn'gu [Myoungsung the Empress]," Yŏksa Bip'yŏng [Critical Review of History] Nov. (2001): 101-119.

34.

"Myŏngsŏng Hwanghu Chaep'yŏngga [Revaluation on Myoungsung the Empress]," Yǒksa Bip'yŏng [Critical Review of History] Sep. (2002): 328-349

35. Ǔn, Chŏngt'ae. "Myŏngsŏng Wanghu Sajin Chinwi Nonjaeng [Dis- 
pute over the authenticity of alleged photographs of Queen Myŏngsŏng]", Yǒksa Bip'yŏng [Critical Review of History] Nov. (2001): 120-128.

36. Yi Minwŏn. "Kŭndae ŭi Kungjung Yŏsŏng - Myŏngsŏng Hwanghu ŭi Kwŏllyŏk kwa Hisaeng [The Last Queen of Chosun Dynasty - Her Political Power and Sacrifice -]," Sahak Yŏn'gu [The Rieview of Korean History] 77 (2005): 65-99.

37. Yi Paeyong. "Kaehwagi Myŏngsŏng Hwanghu Minbi ŭi Chŏngch'ijŏk Yŏk'al [Political Role of Queen Min in the Enlightenment Period]," Kuksagwan Nonch'ong [Bulletin of National Institute of Korean History] 66 (1995): 61-111.

38. Yun Chinyoung. "Kang Sehwang Chak <Pokch'ŏn Oh buin Yŏngjŏng> [Bokchoen Lady Oh's portrait scroll by Kang Sehwang]," Kangjwa Misulsa [The Misulsa], 27 (2006): 259-284. 
$<$ Abstract $>$

\section{The Conundrum of Queen Min's Portrait: a Denied or Partial Identity?}

Queen Min (1851-1895) is described in numerous texts including diaries and newspaper articles written by Western, Japanese and Korean authors who lived in Korea between the late $19^{\text {th }}$ and early $20^{\text {th }}$ centuries. However, she is without visual identity, i.e., facial identity, even though King Kojong (1864-1907) referred to the existence of a portrait. This article holds that visual and non-visual identities are complementary to a person. It argues that in the case of Queen Min, the missing visual record generates a de-personification of her identity and that this contributes to the tarnishing of her public and private role in the period prior to Japan's annexation of Korea. The paper also discusses the history of the queen's visual identity, which is missing from official history, and inquires into its significance.

Keywords: Photography, visual identity, life story, identity role 
〈국문초록〉

\section{명성황후 초상화를 둘러싼 수수께끼: 거부당한 정체성인가 불완전한 정체성인가}

안토네타 L. 브루노, 김국진 (로마 사피엔자 대학교)

명성황후(1851-1895)에 대한 묘사는 한국인을 비롯해 한국에 거주했던 서양인 및 일본인이 19세기 말, 20 세기 초에 남긴 일기, 신문기사 등 수많은 저작물에 등장한다. 고종(1864-1907)은 황후의 초상화가 존재했다고 언급하고 있다. 그러나 명성황후의 시 각적 정체성, 다시 말해 그의 얼굴 내지는 용모가 지니는 정체성은 현재까지도 베일에 싸여 있는데, 여기에는 조선의 왕실 여성 초상 제작에 대한 역사적 맥락 또한 작용하 고 있음을 밝힌다. 본 논문은 한 개인에게 시각적 및 비시각적 정체성이 상호 보완적 이라는 시각에서 명성황후의 경우를 분석하여 외모에 대한 기록의 부재가 그를 탈인격 화하는 결과를 낳았을 뿐만 아니라 이것이 결국 한일병합 이전 시기 그의 위상과 역할 을 퇴색시키는 것으로 이어졌음을 논한다. 아울러 명성황후의 시각적 정체성이 지닌 중요성에 대한 질문 또한 던진다.

주제어: 사진, 시각적 정체성, 일대기, 정체성 역할 